\title{
Micro determination of plasma and erythrocyte copper by atomic absorption spectrophotometry
}

\author{
JEANETTE BLOMFIELD AND R. A. MACMAHON ${ }^{1}$ \\ From The James Fairfax Surgical Research Unit, Children's Medical Research Foundation, \\ Royal Alexandra Hospital for Children, Sydney, NSW, Australia
}

SYNOPSIS The free and total plasma copper and total erythrocyte copper levels have been determined by simple, yet sensitive and highly specific methods, using atomic absorption spectrophotometry. $\omega^{\omega}$

For total copper determination, the copper was split from its protein combination in plasma or 5 red cells by the action of hydrochloric acid at room temperature. The liberated copper was chelated ${ }_{3}^{-}$ by ammonium pyrrolidine dithiocarbamate and extracted into $n$-butyl acetate by shaking and thes organic extract was aspirated into the atomic absorption spectrophotometer flame. The entires procedure was carried out in polypropylene centrifuge tubes, capped during shaking. For the free plasma copper measurement the hydrochloric acid step was omitted.

Removal of the plasma or erythrocyte proteins was found to be unnecessary, and, in addition, the presence of trichloracetic acid caused an appreciable lowering of absorption.

Using a double-beam atomic absorption spectrophotometer and scale expansion $\times 10$, micro methods have been derived for determining the total copper of plasma or erythrocytes with $0 \cdot 1 \mathrm{mb}$ of sample, and the free copper of plasma with $0.5 \mathrm{ml}$. The macro plasma copper method requires $\frac{\Phi}{\Omega}$ $2 \mathrm{ml}$ of plasma and is suitable for use with single-beam atomic absorption spectrophotometers.

With blood from 50 blood donors, normal ranges of plasma and erythrocyte copper have been determined.

This paper describes the development of micro methods for estimating plasma free copper, plasma total copper, and erythrocyte copper using atomic absorption spectrophotometry. A macro method for total plasma copper, suitable for single-beam instruments, is also presented. Macro and micro plasma copper methods have been compared with the 1 in 4 water dilution of plasma.

A number of macro plasma total copper methods using atomic absorption spectrophotometry are available, including those by Herrmann and Lang (1963), Berman (1965), Sprague and Slavin (1965), Parker, Humoller, and Mahler (1967), and Sunderman and Roszel (1967). However, atomic absorption methods have not, to our knowledge, been developed for the micro quantities of plasma available by heel prick from infants, nor for determining the free, noncaeruloplasmin copper of plasma, nor for red cell copper.

\footnotetext{
${ }^{1}$ Present address: Department of Paediatrics, Monash University, Melbourne, Victoria, Australia.

Received for publication 12 July 1968.
}

Clinically the three blood copper levels-free plasma copper, total plasma copper, and red cello copper-are of particular value in diagnosing or ex cluding Wilson's disease, and in assessing copperô contamination or poisoning and copper deficiency.

In Wilson's disease the total plasma copper iso usually low with a low level of caeruloplasmin but increased free copper, whereas other types of liver? cirrhosis usually have high plasma copper and caeruloplasmin levels. The haemolytic episodes of Wilson's disease have recently been shown to bes associated with high red cell copper and increased plasma free copper (McIntyre, Clink, Levi, Cumings, and Sherlock, 1967). The severity of copper poison ing correlates better with the whole blood or red celle copper level than the plasma copper level (Chuttani, Gupta, Gulati, and Gupta, 1965). Copper deficiencyo in ill-nourished infants has been suggested by theo response of anaemia and osteoporosis to coppero supplements, but the deficiency has not been con- ${ }^{\circ}$ firmed by blood copper studies (Cordano, Baertl, andoGraham, 1964; Cordano and Graham, 1966). 
To allow of the measurement of blood copper levels by micro methods or with a single-beam instrument, the copper has been chelated by ammonium pyrrolidine dithiocarbamate (APD) and extracted into an organic solvent (Allan, 1961a). A fourfold increase in the sensitivity of the copper measurement is thus achieved (Allan, 1961b). For the measurement of the total plasma copper or red cell copper, the copper was split from the copper-protein complexes, caeruloplasmin and erythrocuprein, by hydrochloric acid before chelation (Gubler, Lahey, Ashenbrucker, Cartwright, and Wintrobe, 1952). For the free plasma copper determination no acid was used, and only the non-caeruloplasmin copper, which reacted directly with APD, was extracted and measured (Gubler, Lahey, Cartwright, and Wintrobe, 1953). A comparison has also been made of the plasma macro and micro total copper methods with the simple 1 in 4 dilution of plasma and aqueous copper sulphate standards with water.

\section{METHODS}

The preliminary work for these methods was carried out with single-beam atomic absorption spectrophotometers. The results presented here were repeated, and the micro methods were developed, using a Perkin-Elmer 303 double-beam atomic absorption spectrophotometer made by the Perkin-Elmer Corporation, Norwalk, Connecticut, USA. A three-slot Boling burner head (Boling, 1966) was used, and with it negligible copper blanks were obtained. However, it was found to be necessary to replace the rubber O-rings and gasket in the atomizerburner assembly by teflon substitutes because the reagents attacked the rubber and liberated copper from it. A nylon drain tube, which was resistant to butyl acetate, was substituted for the tygon tubing. The hollow cathode copper lamp was made by Atomic Spectral Lamps Pty. Ltd, Melbourne, Victoria, Australia.

An air-acetylene flame was used with the acetylene pressure reduced so that a hazy blue flame resulted when the butyl acetate was sprayed into it. The wavelength was set at $3,247 \AA$. Scale expansion $\times 1$ was used for the macro plasma method, and $\times 10$ for all other methods.

All laboratory ware and pipettes were washed with detergent and rinsed with deionized water, then soaked overnight in 1 in 4 nitric acid and again rinsed thoroughly with deionized water. Only borosilicate glass or polypropylene were used. Disposable polypropylene syringes, needles, and the heparin were tested to ensure that they were free of copper.

REAGENTS Deionized water was prepared with the Permutit mark 7 Deminrolit.

A stock copper solution of $1,000 \mathrm{ppm}$ was prepared by dissolving $3.9279 \mathrm{~g} \mathrm{CuSO}_{4} .5 \mathrm{H}_{2} \mathrm{O}$ (British Drug Houses, AnalaR) in 1 litre of deionized water. Working standards over the range of 5 to $300 \mu \mathrm{g} / 100 \mathrm{ml}, i e, 0.05$ to $3 \mathrm{ppm}$, were prepared by dilution with deionized water.

4N Hydrochloric acid was prepared by dilution of concentrated hydrochloric acid (British Drug Houses, AnalaR). To remove traces of copper, the acid was shaken in a separating funnel with ammonium pyrrolidine dithiocarbamate in n-butyl acetate, and then shaken again with n-butyl acetate alone.

Solutions of 0.1 and $0.25 \%$ aqueous ammonium pyrrolidine dithiocarbamate (APD) (Univar, Ajax Chemicals Ltd, Sydney, Australia) were made up fresh daily in deionized water.

n-Butyl acetate (May \& Baker) was shaken with dilute hydrochloric acid followed by deionized water, to remove contaminating copper.

\section{PROCEDURES}

MACRO METHOD FOR PLASMA COPPER (BLOMFIELD, MACMAHON, AND HALLIDAY, 1966) To a $15 \mathrm{ml}$ capped polypropylene centrifuge tube, ${ }^{1}$ add $2 \mathrm{ml}$ of either plasma, copper standards, or deionized water blank, then add, with shaking, $2 \mathrm{ml} 4 \mathrm{~N} \mathrm{HCl}$. Stand for 10 minutes at room temperature. Add $2 \mathrm{ml} 0.1 \%$ ammonium pyrrolidine dithiocarbamate (APD) and mix. Add $2 \mathrm{ml} \mathrm{n}$-butyl acetate, cap the tube, and shake for 10 minutes on a flask shaker. Centrifuge for five minutes, and pipette off the top n-butyl acetate layer with an acid-washed borosilicate glass Pasteur pipette. Aspirate into the atomic absorption spectrophotometer flame, and read the absorption at $3,247 \AA$ using scale expansion $\times 1$.

MICRO METHOD FOR PLASMA COPPER Plasma, copper standard, or deionized water, $\mathbf{0 \cdot 1} \mathbf{m l}$, is pipetted into a centrifuge tube, $0.1 \mathrm{ml} .4 \mathrm{~N} \mathrm{HCl}$ is added, and the mixture left at room temperature for 10 minutes. Then $0.1 \mathrm{ml}$ $0.1 \%$ APD is added, followed by $2.0 \mathrm{ml} \mathrm{n}$-butyl acetate. The tube is stoppered, shaken for 10 minutes, and centrifuged for five minutes. The n-butyl acetate layer is removed and aspirated into the atomic absorption flame, and read using scale expansion $\times 10$.

1 IN 4 WATER DILUTION METHOD FOR PLASMA COPPER Plasma, $0.5 \mathrm{ml}$, is added to $1.5 \mathrm{ml}$ deionized water. This is aspirated into the flame and read against appropriate aqueous copper standards with scale expansion $\times 10$.

FREE PLASMA COPPER METHOD Into a centrifuge tube are pipetted $0.5 \mathrm{ml}$ plasma, copper standards, or deionized water, followed by $0.5 \mathrm{ml} 0.1 \%$ APD and $2 \mathrm{ml} \mathrm{n}$-butyl acetate. The tubes are stoppered, shaken for 10 minutes, and centrifuged for five minutes. The n-butyl acetate layer is aspirated into the atomic absorption flame, and read using scale expansion $\times 10$.

MICRO METHOD FOR ERYTHROCYTE COPPER Packed red cells, copper standards, or deionized water, $0.1 \mathrm{ml}$, is pipetted into $0.4 \mathrm{ml}$ deionized water in a centrifuge tube. $4 \mathrm{~N} \mathrm{HCl}, 0.05$, is added and allowed to react for 10 minutes at room temperature. Then $0.1 \mathrm{ml} 0.25 \%$ APD is added and $2.0 \mathrm{ml} \mathrm{n}$-butyl acetate. The tubes are stoppered, shaken on a flask shaker for 10 minutes, and centrifuged for five minutes. The n-butyl acetate layer is removed, aspirated into the atomic absorption flame, and read with scale expansion $\times 10$.

'Disposable Products, Adelaide, South Australia, Australia. 
RESULTS WITH MACRO AND MICRO METHODS FOR PLASMA COPPER

OPTIMUM CONCENTRATION OF HYDROCHLORIC ACID With $2 \mathrm{~N}$ or weaker concentrations of $\mathrm{HCl}$, an emulsion occurred in the butyl acetate layer which made removal of the butyl acetate very difficult. With $4 \mathrm{~N}$, $6 \mathrm{~N}$, and $8 \mathrm{~N} \mathrm{HCl}$, the proteins formed a firm button under the organic layer, and the butyl acetate could be readily removed with a Pasteur pipette. No more copper was released by $6 \mathrm{~N}$ or $8 \mathrm{~N} \mathrm{HCl}$ than with $4 \mathrm{~N}$ $\mathrm{HCl}$, so the latter weaker and less noxious concentration was used.

TIME AND TEMPERATURE OF THE REACTION WITH HCL No more copper was recovered when the $4 \mathrm{~N} \mathrm{HCl}$ was left in contact with the plasma for one hour at $37^{\circ}$ than for 10 minutes at room temperature, so the $\mathrm{HCl}$ was allowed to react by leaving the tubes on the bench for 10 minutes.

CONCENTRATION OF AMMONIUM PYRROLIDINE DITHIOCARBAMATE (APD) Little difference was found in plasma copper values with concentrations of APD ranging from 0.01 to $2.5 \%$ (Fig. $1 \mathrm{~A}$ and $\mathrm{B}$ ). In the macro method (Fig. 1 A) with 1.0 and $2.5 \%$ APD, the APD was precipitated on its addition to the acidified plasma, a slight turbidity was seen in the butyl acetate layer, and the atomizer tended to clog. With $0.01 \%$ APD values were variable, possibly due to competition by other ions. Concentrations of $0.05,0.1$, and $0.25 \%$ gave identical values, and the midconcentration of $0 \cdot 1 \%$ has been chosen for macro and micro methods.

SHAKING TIME WITH N-BUTYL ACETATE Although the aqueous copper standards were rapidly extracted

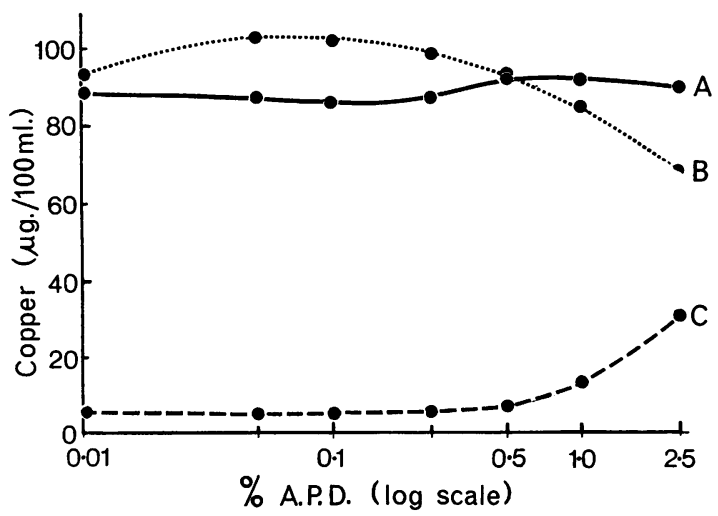

FIG. 1. The effect of the concentration of ammonium pyrrolidine dithiocarbamate $(A P D)$ on the determination of total and free plasma copper. A plasma macro method; B plasma micro method; C plasma free copper method. into the butyl acetate, with plasma the shaking had to을 be sufficiently long and vigorous to ensure complete extraction of the copper complex into the organic layer. Using the stoppered centrifuge tubes botho macro and micro methods required 10 minutes'음 shaking at maximum speed on the flask shaker ${ }^{1}$ to $\frac{\bar{\rho}}{\bar{D}}$ obtain optimum extraction.

STABILITY OF THE COPPER-APD COMPLEX With aqueous copper standards no copper was lost from. the butyl acetate layer to the aqueous layer after 60 minutes' standing.

THE EFFECTS OF TRICHLORACETIC ACID Proteini removal by trichloracetic acid was not only found to $N$ be unnecessary when $4 \mathrm{~N} \mathrm{HCl}$ was used, but in addi- tion $20 \%$ trichloracetic acid produced a $40 \%$ reduc- $\omega$ tion in absorption with the aqueous copper standards응 and a $33 \%$ reduction with plasma. This depressioncould be reversed completely in the aqueous stand- $\bar{z}$ ards and partly in the plasma by neutralization before extraction. No loss of copper from the butyl acetate $\stackrel{\supset}{\supset}$ layer was found on standing in the presence of tri- $\vec{\theta}$ chloracetic acid (such as had been reported by 8 Herrmann and Lang) even when sodium diethyldithiocarbamate was substituted for APD.

RESUltS AFTER DILUTION OF PLASMA WITH WATER

SERIAL DILUTIONS Using scale expansion $\times 10$, the mean values of five determinations of dilutions of plasma by deionized water of 1 in 2,1 in 3,1 in 4, 1 in 5 , and 1 in 6 were $112,118,123,132$, and 142 ? $\mu \mathrm{g} / 100 \mathrm{ml}$ respectively. Thus there was a progressive increase in value with increasing dilution. The 1 in 48 water dilution is a quick and simple method which gives values which are sufficiently accurate for many clinical purposes. It is ideal as a screening test.

\section{RESULTS IN FREE PLASMA COPPER METHOD}

CONCENTRATION OF APD The amount of plasma $\frac{7}{5}$ copper reacting directly with APD was little affected by the concentration of APD over the range $0.01 \mathrm{~N}$ to $0.5 \%$ (Fig. $1 \mathrm{C}$ ). With increasing concentrations $N$ the amount of copper chelated rose, suggesting that $N$ the caeruloplasmin copper was being slowly liber- 0 ated. Ammonium pyrrolidine dithiocarbamate $0.1 \%$ appeared to be a suitable concentration for both $\bar{\Phi}_{\mathscr{D}}$ total and free plasma copper.

EFFECT OF TIME ON DIRECT CHELATION OF COPPER Using $0.1 \%$ APD, no more plasma copper reacted directly with APD when it was left to react for $\mathbb{D}$ 60 minutes, compared with the immediate addition ${ }^{1}$ Griffin \& George, London, England 


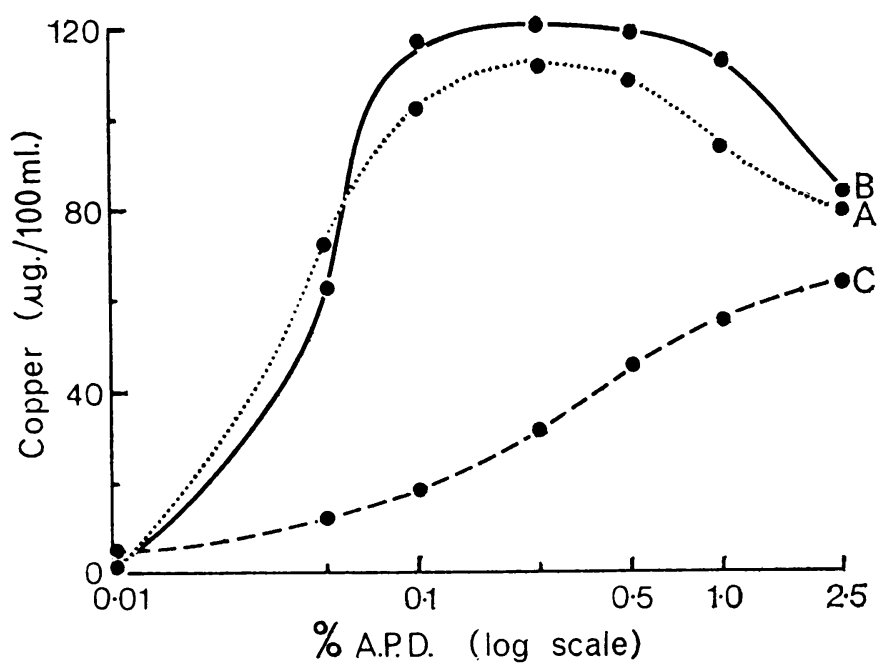

FIG. 2. The effect of the concentration of ammonium pyrrolidine dithiocarbamate $(A P D)$ on the determination of total and free erythrocyte copper. A erythrocyte copper method; B ratio of $\mathrm{Fe}: \mathrm{Cu}$ of 1,000:I in aqueous copper standards of $100 \mu \mathrm{g}$ $\mathrm{Cu} / 100 \mathrm{ml} ; \mathrm{C}$ erythrocyte free copper method.

of the butyl acetate after the APD. With $2.5 \%$ APD copper was slowly split from caeruloplasmin so that after 24 hours about half the total plasma copper was chelated by the APD (Table I).

\section{TABLE I}

EFFECT OF TIME ON AMOUNT OF DIRECT-REACTING COPPER CHELATED BY $2.5 \%$ APD IN PLASMA AND ERYTHROCYTES

\begin{tabular}{lll} 
Time & $\begin{array}{l}\text { Plasma } \\
(\mathrm{Cu} \mu \mathrm{g} / 100 \mathrm{ml})\end{array}$ & $\begin{array}{l}\text { Erythrocytes } \\
(\mathrm{Cu} \mu \mathrm{g} / 100 \mathrm{ml})\end{array}$ \\
\hline $0 \mathrm{~min}$ & 9 & 43 \\
$10 \mathrm{~min}$ & 10 & 54 \\
$1 \mathrm{hr}$ & 11 & 61 \\
$4 \mathrm{hr}$ & 19 & 67 \\
$24 \mathrm{hr}$ & 52 & 71
\end{tabular}

\section{RESULTS IN MICRO METHOD FOR ERYTHROCYTE COPPER}

CONCENTRATION OF HCL The concentration of $\mathrm{HCl}$ added was again $4 \mathrm{~N}$, but only half the volume added to plasma was used. In addition, water was added to the packed red cells before the acid, not only to lyse the cells, but also to lower the concentration of $\mathrm{HCl}$ in the reaction mixture. With the conditions specified in the method, only minimal protein precipitation occurred. When a higher proportion of $\mathrm{HCl}$ was used, the erythrocyte proteins formed a solid precipitate, and the values for copper were lower, probably because the APD and the butyl acetate were unable to penetrate the solid protein mass and the copper could not be completely extracted.

TIME AND TEMPERATURE OF HCL No more copper was obtained by leaving the $\mathrm{HCl}$ to react for one hour at $37^{\circ}$ compared with 10 minutes at room temperature, so the latter, simpler conditions were used.
CONCENTRATION OF APD The amount of chelated copper extracted from $\mathrm{HCl}$-treated red cells was dependent on the concentration of APD, the optimum concentration being $0.25 \%$ (Fig. 2 A). With APD concentrations of $0.05 \%$ and lower, and of $1.0 \%$ and higher, the amount of copper extracted was significantly decreased.

THE EFFECT OF A HIGH IRON:COPPER RATIO Allan (1961a) found that copper was chelated and extracted from a mixture in which the ratio of iron:copper was $10,000: 1$, provided the acidity was not too high and the concentration of APD was not too great.

Iron was added to a copper standard of $100 \mu \mathrm{g} / 100$ $\mathrm{ml}$ in the ratio of $1,000: 1$. The acid conditions of the erythrocyte copper method were used, and concentrations of APD of from 0.01 to $2.5 \%$ were tested (Fig. 2 B). With concentrations of APD between 0.1 and $1.0 \%$ all of the copper was extracted, and the copper readings were enhanced by about $20 \%$. With $0.01 \%$ APD, no copper was recovered, and with 0.05 and $2.5 \%$ APD, the copper was not completely extracted.

FREE ERYTHROCYTE COPPER An attempt was made to measure free copper in erythrocytes, that is, copper chelated without prior $\mathrm{HCl}$ treatment. Water, $0.5 \mathrm{ml}$, was added to $0.5 \mathrm{ml}$ packed red cells to lyse them. Then $0.5 \mathrm{ml}$ APD was added and the chelated copper was extracted with $2 \mathrm{ml}$ butyl acetate.

The amount of erythrocyte copper that reacted directly with APD was dependent on the concentration of APD (Fig. $2 \mathrm{C}$ ), and the time allowed for the reaction (Table I), and it appeared that much, or all, of the total erythrocyte copper could, in time, be directly chelated. In contrast to plasma, immediate 
chelation of nearly half the red cell copper by $2.5 \%$ APD was found to occur (Table I).

\section{STANDARD CURVES}

With the copper standards the relationship of concentration to absorption was linear in all methods except the macro plasma method in which a curve resulted (Fig. 3). Conversion of absorption to absorbance resulted in a linear relationship in the macro method.

\section{REPRODUCIBILITY}

The reproducibility of the five methods of determining copper in blood was assessed by performing duplicate determinations on 10 different days with aliquots from a single blood sample.

The means and standard deviations for reproducibility of the different methods are shown in Table II.

The better reproducibility with the macro method was due partly to the readings being made without

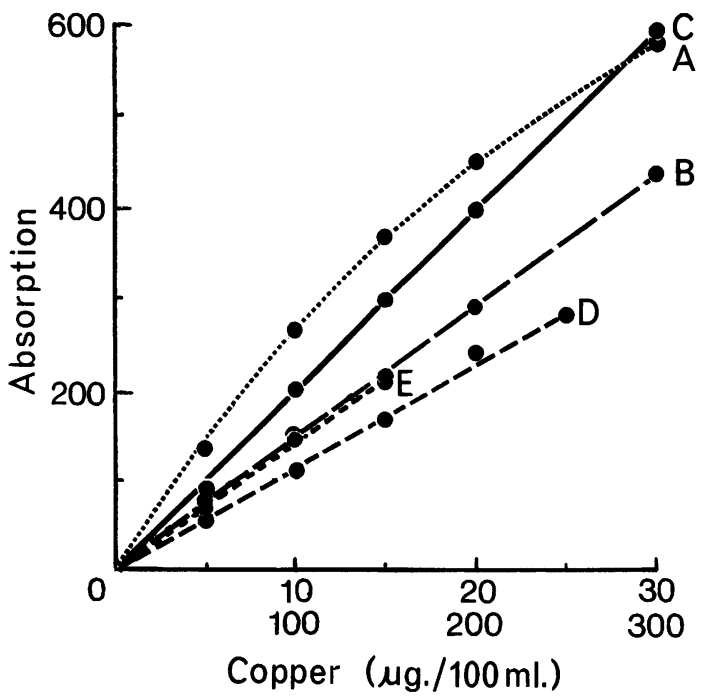

FIG. 3. The relationship of the concentration of copper to absorption with aqueous copper standards. A plasma macro method; B plasma micro method; C plasma 1 in 4 water dilution method; D plasma free copper method; E erythrocyte copper method. The free copper standards are in the concentration range of 5 to $25 \mu \mathrm{g} / 100 \mathrm{ml}$, and all other standards are within the range of 50 to $300 \mu \mathrm{g} / 100 \mathrm{ml}$.

any scale expansion on the atomic absorption spectrophotometer, whereas all the other methods used scale expansion $\times 10$.

The use of an analog computer or recorder would improve reproducibility.
TABLE II

REPRODUCIBILITY OF DIFFERENT METHODS FOR ESTIMATING COPPER IN PLASMA AND ERYTHROCYTES DETERMINED IN DUPLICATE ON 10 SEPARATE DAYS

\begin{tabular}{lll} 
Method & $\begin{array}{l}\text { Mean and } S D \\
\text { Copper } \\
(\mu g / 100 ~ m l)\end{array}$ & $\begin{array}{l}\text { Coefficient of } \\
\text { Variation of } \\
\text { Reproducibility } \\
(\%)\end{array}$ \\
\hline Plasma macro & $102 \pm 1 \cdot 7$ & $1 \cdot 7$ \\
Plasma micro & $122 \pm 12 \cdot 3$ & $10 \cdot 1$ \\
Plasma 1 in 4 water dilution & $126 \pm 5 \cdot 7$ & $4 \cdot 5$ \\
Plasma free copper & $5.9 \pm 1 \cdot 1$ & 18.6 \\
Erythrocyte copper & $92 \pm 9 \cdot 7$ & 10.5
\end{tabular}

\section{RECOVERY}

The recovery of copper added to plasma or erythrocytes has been determined for the five methods $\omega$ (Table III). Added copper was not completely recovered in the macro plasma method. In the micro plasma method recovery of added copper tended to $z$ be slightly high, and in the 1 in 4 water dilution method and the free plasma copper method re- $\supset$ coveries were slightly low. In the erythrocyte method $\vec{\theta}$ the absorption of added copper was to some extent 8 enhanced.

TABLE III

RECOVERY OF COPPER IN THE DIFFERENT METHODS FOR ESTIMATING COPPER IN PLASMA AND ERYTHROCYTES

\begin{tabular}{|c|c|c|c|}
\hline Method & $\begin{array}{l}\text { Amount of } \\
\text { Copper } \\
\text { Added } \\
(\mu g \%)\end{array}$ & $\begin{array}{l}\text { Mean Recovery } \\
\text { and } S . D . \\
\text { Copper } \\
(\mu \mathrm{g} / 100 \mathrm{ml})\end{array}$ & $\begin{array}{l}\text { Percentage } \\
\text { Recovery }\end{array}$ \\
\hline Plasma macro & $\begin{array}{r}50 \\
100\end{array}$ & $\begin{array}{l}46 \pm 3 \cdot 1 \\
94 \pm 4 \cdot 3\end{array}$ & $\begin{array}{l}92 \\
94\end{array}$ \\
\hline Plasma micro & $\begin{array}{r}50 \\
100\end{array}$ & $\begin{array}{r}53 \pm 3 \cdot 0 \\
104 \pm 8 \cdot 2\end{array}$ & $\begin{array}{l}106 \\
104\end{array}$ \\
\hline $\begin{array}{l}\text { Plasma } 1 \text { in } 4 \text { water } \\
\text { dilution }\end{array}$ & $\begin{array}{r}50 \\
100\end{array}$ & $\begin{array}{l}47 \pm 5 \cdot 9 \\
99 \pm 5 \cdot 6\end{array}$ & $\begin{array}{l}94 \\
99\end{array}$ \\
\hline Plasma free copper & $\begin{array}{r}5 \\
10\end{array}$ & $\begin{array}{r}4.6 \pm 0.26 \\
10.0 \pm 0.38\end{array}$ & $\begin{array}{r}92 \\
100\end{array}$ \\
\hline Erythrocyte copper & $\begin{array}{r}50 \\
100\end{array}$ & $\begin{array}{r}53 \pm 5 \cdot 7 \\
111 \pm 5 \cdot 4\end{array}$ & $\begin{array}{l}105 \\
111\end{array}$ \\
\hline
\end{tabular}

\section{ADULT NORMAL RANGES}

The normal ranges for blood copper levels by the five methods have been determined using heparinized blood from 25 male and 25 female blood donors in the age range of 18 to 60 years.

Three of the female donors had plasma copper levels greater than $200 \mu \mathrm{g} / 100 \mathrm{ml}$, possibly due to taking oral contraceptives. Carruthers, Hobbs, and Warren (1966) have found that the taking of oral $\mathbb{\Phi}$ contraceptives raised serum copper levels to within the range of 180 to $335 \mu \mathrm{g} / 100 \mathrm{ml}$ compared with 
their normal range 95 to $140 \mu \mathrm{g} / 100 \mathrm{ml}$. These three females with elevated levels have been excluded from the normal values for means, standard deviations, and ranges presented in Table IV, but not from the frequency distributions shown in Figures 4, 5, and 6.

Although the normal range of plasma values was

\section{TABLE IV}

ADULT NORMAL VALUES FOR COPPER IN PLASMA AND ERYTHROCYTES DETERMINED BY THE DIFFERENT METHODS

\begin{tabular}{|c|c|c|c|c|}
\hline \multirow[t]{3}{*}{ Method } & \multicolumn{2}{|l|}{ Males } & \multicolumn{2}{|l|}{ Females } \\
\hline & \multicolumn{2}{|c|}{ Copper $(\mu \mathrm{g} / 100 \mathrm{ml})$} & \multicolumn{2}{|c|}{ Copper $(\mu \mathrm{g} / 100 \mathrm{ml})$} \\
\hline & Mean S.D. & Range & Mean S.D. & Range \\
\hline $\begin{array}{l}\text { Plasma macro } \\
\text { Plasma micro } \\
1 \text { in } 4 \text { dilution } \\
\text { Plasma free } \mathrm{Cu} \\
\text { Erythrocyte } \mathrm{Cu}\end{array}$ & $\begin{array}{c}107 \pm 18.2 \\
115 \pm 20.9 \\
119 \pm 17.5 \\
9.0 \pm 1.4 \\
95 \pm 5.4\end{array}$ & $\begin{array}{c}79-155 \\
87-165 \\
91-163 \\
6-12 \\
86-106\end{array}$ & $\begin{array}{c}118 \pm 25 \cdot 4 \\
125 \pm 26 \cdot 9 \\
126 \pm 25 \cdot 8 \\
9 \cdot 1 \pm 2 \cdot 1 \\
89 \pm 8 \cdot 5\end{array}$ & $\begin{array}{c}74-160 \\
81-167 \\
82-167 \\
6-16 \\
76-106\end{array}$ \\
\hline
\end{tabular}

essentially the same for males and females, the females had mean values by all three methods which were higher by about $10 \%$ than the male means.

With the free plasma copper, there was a tendency for the levels to increase as the total plasma level rose. The three females with the abnormally high plasma copper levels of 201,207 , and $229 \mu \mathrm{g} / 100 \mathrm{ml}$ by the macro method had free copper values of 13 , 12 , and $14 \mu \mathrm{g} / 100 \mathrm{ml}$ respectively.

The erythrocyte copper levels fell within a much narrower range than the plasma copper levels (Table

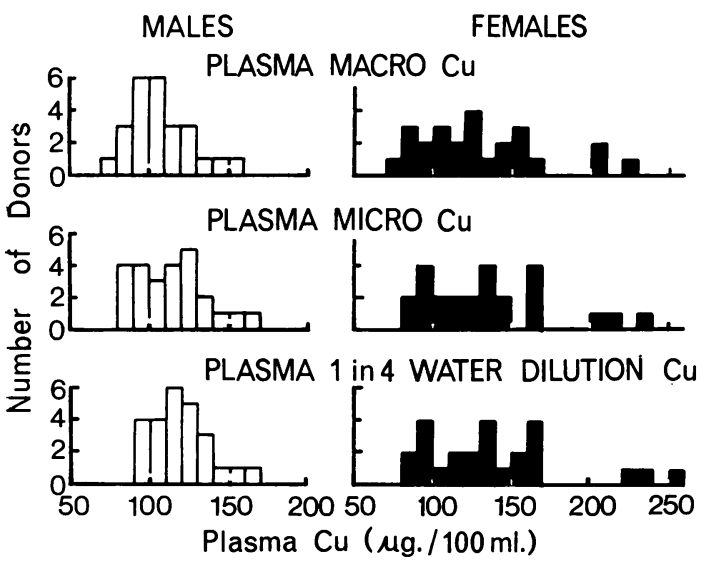

FIG. 4. The frequency distribution of plasma total copper for 25 male and 25 female blood donors by the macro method, the micro method, and the 1 in 4 water dilution method.

IV and Fig. 6). No significant sex difference could be determined by this micro method, and the total and

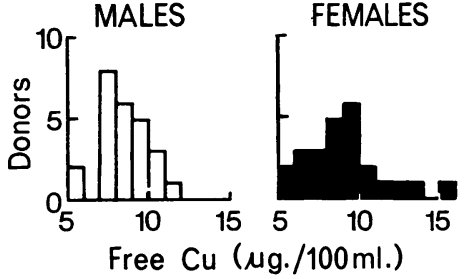

FIG. 5. The frequency distribution of plasma free copper for 25 male and 25 female blood donors.

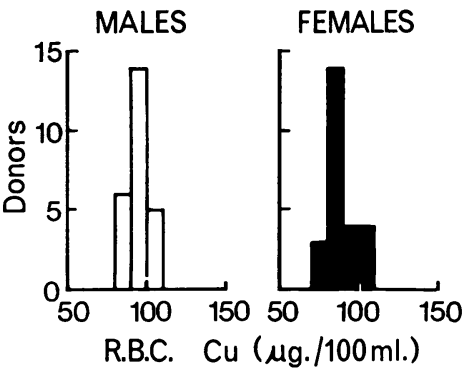

FIG. 6. The frequency distribution of erythrocyte copper for 25 male and 25 female blood donors.

free plasma copper levels did not appear to influence the red cell copper levels.

COMPARISON OF TOTAL PLASMA COPPER DETERMINED BY ATOMIC ABSORPTION AND COLORIMETRIC METHODS

A comparison has been made of the levels of total plasma copper determined by the macro, micro, and 1 in 4 water dilution methods, and by the colorimetric methods of Gubler et al (1952) and of Beale and Croft (1964). In both the colorimetric methods, the caeruloplasmin copper is liberated by $\mathrm{HCl}$ and the proteins are precipitated by trichloracetic acid. In the method of Gubler et al, the copper is determined by the increase of yellow colour on the addition of sodium diethyldithiocarbamate, and in the method of Beale and Croft by the measurement of the more specific and sensitive blue-red colour of the oxalyldihydrazide copper complex.

There was excellent agreement between the macro method and the colorimetric method of Beale and Croft with low, normal, and high plasma copper levels (Table V). In our hands, the method of Gubler et al produced lower copper values, particularly with the lower copper concentrations. At the low concentrations, the increase of optical density is very small on the addition of sodium diethyldithiocarbamate, and the blank reading is relatively high, so that the order of accuracy is diminished. With our micro method the results were slightly higher than with the colorimetric method of Beale and Croft, and the 1 in 4 water dilution method gave results which were higher again. 


\section{TABLE V}

COMPARISON OF TOTAL PLASMA COPPER DETERMINED BY THE COLORIMETRIC METHODS AND BY THE ATOMIC ABSORPTION METHODS $^{1}$

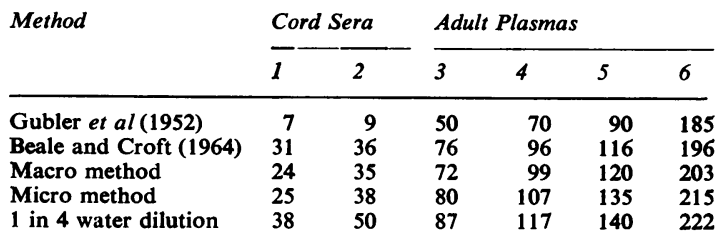

${ }^{1}$ Samples 1 and 2 were sera from cord blood, 3 to 5 were heparinized plasmas from adults, and 6 was plasma from an adult female taking oral contraceptives.

\section{DISCUSSION}

Atomic absorption spectrophotometry provides a rapid and specific means of measuring copper. The single-beam instrument is sufficiently sensitive to measure copper in the concentrations found in blood plasma if sufficient blood is available. With the increased stability and sensitivity of the double-beam instrument, the amount of copper extracted from a small diluted plasma or red cell sample comes within the measurable range, as does the trace quantity of free copper in the plasma.

The colorimetric methods for measuring plasma and red cell copper, in which copper was measured as an increase in yellow colour on the addition of sodium diethyldithiocarbamate (Gubler et al, 1952; Gubler et al, 1953), were liable to error due to the low colour yield and the presence of interfering colours. In highly icteric sera the free copper could not be satisfactorily measured by the small increase of yellow colour (Gubler, Brown, Markowitz, Cartwright, and Wintrobe, 1957). In jaundiced patients, the atomic absorption free copper method should be of particular value in distinguishing Wilson's disease from other types of liver cirrhosis.

The blue-red colour of the copper oxalyldihydrazide complex has greater intensity and specificity, and the method of Beale and Croft (1964) gave excellent agreement with our plasma macro and micro methods. The spectrophotometric method for erythrocyte copper using oxalyldihydrazide of Markowitz, Shields, Klassen, Cartwright, and Wintrobe (1961) is long and involved, requiring two days for completion, three changes of reaction vessel, and some 20 pipettings, so that the greater speed and simplicity of our method is readily apparent.

In comparison with other atomic absorption methods for measuring plasma copper using chelation and extraction (Herrmann and Lang, 1963; Berman, 1965), we have avoided the use of trichloracetic acid. Instead, we use a stronger concentration of hydrochloric acid which effectively precipitates $\stackrel{\vec{\sigma}}{\overrightarrow{0}}$ the plasma proteins and prevents emulsification. We consider that trichloracetic acid is undesirable be- $\stackrel{\bar{S}}{\stackrel{5}{9}}$ cause of the decrease in sensitivity it produces by음 lowering the absorption readings of both standards 흠 and tests; because of the extra time involved in $\frac{\bar{\rho}}{5}$ protein precipitation and removal; and because of $\stackrel{\mathbb{\complement}}{\propto}$ the necessity for quantitative transfer of the super- 0 natant to a second tube. However, if the plasma $\rightarrow$ proteins are not removed, the copper complex is? more difficult to extract into the butyl acetate, and it $\vec{\omega}$ is recommended that the optimum shaking condi- $\rho$ tions be determined in each laboratory.

The concentration of the chelating agent, am-in monium pyrrolidine dithiocarbamate (APD), was ${ }_{N}^{N}$ not critical in the plasma copper methods, although in the free copper method high concentrations of ${ }^{\omega}$ APD did, in time, split some of the copper from the을 caeruloplasmin.

With the erythrocyte copper, the concentration of 3 APD had to be kept within a narrow range. This was probably due to the high levels of iron, and possibly of zinc, which compete for the chelating agent if the $\overrightarrow{0}$ concentration is too low, and to the interference by iron which has been shown by Allan (1961a) to occuro when higher concentrations of APD are used. Al-O though we have shown that iron causes enhanced absorption when present in the ratio of 1,000:1, we have not added iron to the standards since little of $\bar{Q}$ the iron in the red cells appeared to the naked eye to be extracted, as the brown iron chelate, into the윽 butyl acetate.

The extraction of the copper into an organic solvent greatly increases the sensitivity of the method: (Allan, 1961b), and also separates the copper from? some of the plasma constituents which might depresso or enhance its absorption, such as protein, sodium, potassium, and calcium (Allan, 1961a).

With the 1 in 4 water dilution method, differences in viscosity between tests and standards (and there-o fore of flow rates) may influence the results (Sprague $>$ and Slavin, 1965; Parker et al, 1967; Sunderman and으․ Roszel, 1967). However, the greater viscosity of the plasma samples compared with the aqueous stand- - r ards would diminish the plasma copper estimates, 0 whereas the results by this method are higher than by the other methods we employed. This suggestso enhancement of the plasma copper readings by someo plasma factor, or depression of the aqueous copper standards, possibly by the sulphate.

Our normal ranges and mean values (Table IV) are similar to those reported by other workers. There is good agreement with the plasma copper levels of Nielsen (1944), Cartwright and Wintrobe (1964), and Sunderman and Roszel (1967) with the direct- reacting plasma copper levels of Cartwright and 
Wintrobe (1964) and with the erythrocyte copper levels of Markowitz et al (1961).

With the aid of atomic absorption spectrophotometry, blood copper estimations can be regarded as relatively simple laboratory procedures.

We wish to thank Dr J. P. Halliday and Mr D. C. Mears of the Department of Surgery, University of Sydney, and Dr G. T. Archer and Miss Annette Angyal of the Red Cross Blood Transfusion Service, Sydney, for their generosity in making available single-beam atomic absorption spectrophotometers, on which the preliminary work for this paper was performed. We would also like to thank the Red Cross Blood Transfusion Service in Sydney for collecting blood samples for our normal controls series, and for making available blood from haemochromatosis patients.

\section{REFERENCES}

Allan, J. E. (1961a). Spectrochim. Acta, 17, 459. (1961b). Ibid., 17, 467.

Beale, R. N., and Croft, D. (1964). J. clin. Path., 17, 260.
Berman, E. (1965). Perkin-Elmer Atom. Absorption Newsl., 4, 296. Blomfield, J., MacMahon, R. A., and Halliday, J. P. (1966). Proc. Aust. Ass. clin. Biochem., 1, 229 (Abstr.).

Boling, E. A. (1966). Spectrochim. Acta, 22, 425.

Carruthers, M. E., Hobbs, C. B., and Warren, R. L. (1966). J. clin. Path., 19, 498.

Cartwright, G. E., and Wintrobe, M. M. (1964). Amer. J. clin. Nutr., $14,224$.

Chuttani, H. K., Gupta, P. S., Gulati, S., and Gupta, D. N. (1965). Amer. J. Med., 39, 849.

Cordano, A., Baertl, J. M., and Graham, G. G. (1964). Pediatrics, 34, 324.

_, and Graham, G. G. (1966). Ibid., 38, 596.

Gubler, C. J., Brown, H., Markowitz, H., Cartwright, G. E., and Wintrobe, M. M. (1957). J. clin. Invest., 36, 1208.

-, Lahey, M. E., Ashenbrucker, H., Cartwright, G. E., and Wintrobe, M. M. (1952). J. biol. Chem., 196, 209.

,- Cartwright, G. E., and Wintrobe, M. M. (1953). J. clin. Invest., 32, 405.

Herrmann, R., and Lang, W. (1963). Z. klin. Chem., 1, 182.

McIntyre, N., Clink, H. M., Levi, A. J., Cumings, J. N., and Sherlock, S. (1967). New Engl. J. Med., 276, 439.

Markowitz, H., Shields, G. S., Klassen, W. H., Cartwright, G. E., and Wintrobe, M. M. (1961). Analyt. Chem., 33, 1594.

Nielsen, A. L. (1944). Acta med. scand., 118, 87.

Parker, M. M., Humoller, F. L., and Mahler, D. J. (1967). Clin. Chem., $13,40$.

Sprague, S., and Slavin, W. (1965). Perkin-Elmer Atom. Absorption Newsl., 4, 228.

Sunderman, F. W., Jr, and Roszel, N. O. (1967). Amer. J. clin. Path., $48,286$. 